\title{
STUDI RETROSPEKTIF PENYALAHGUNAAN OBAT PADA PASIEN KETERGANTUNGAN OBAT DI RUMAH SAKIT JIWA SAMBANG LIHUM
}

\author{
RETROSPECTIVE STUDY OF DRUG ABUSE ON DRUG \\ ADDICTION PATIENS IN SAMBANG LHIUM \\ MENTAL HOSPITAL
}

\author{
Nada Windayanti Miratulhusda, Noor Cahaya, Fadilaturrahmah \\ Program Studi Farmasi Fakultas Matematika dan Ilmu Pengetahuan Alam, Universitas \\ Lambung Mangkurat \\ Email:noorcahaya.farmasiunlam@gmail.com
}

\begin{abstract}
ABSTRAK
Penyalahgunaan obat di Indonesia mengalami peningkatan setiap tahunnya. Penelitian ini bertujuan memberikan gambaran karakteristik pasien ketergantungan obat, pola penyalahgunaan obat, status rehabilitasi pasien ketika keluar dari rumah sakit dan mengetahui hubungan karakteristik pasien dan pola penyalahgunaan obat terhadap status pengobatan pasien ketika keluar dari rumah sakit. Penelitian ini merupakan penelitian observasional dengan pendekatan cross sectional dan pengambilan data secara retrospektif. Pengumpulan data dilakukan melalui rekam medik pasien periode Januari 2012-Desember 2013. Analisis data menggunakan uji statistik Frequency dan Chi-Square. Hasil penelitian menunjukkan pasien dengan tingkat pendidikan terakhir SD persentasenya $34,2 \%$; SMP 36,8\%; SMA 26,3\% dan D3 2,6\%. Pasien menyalahgunakan obat pertama kali pada usia 11-19 tahun persentasenya 50,0\%, 20-29 tahun 42,1\% dan 30-39 tahun $7,9 \%$. Pola penyalahgunaan obat untuk jenis NAPZA persentasenya $26,3 \%$; non NAPZA $13,3 \%$ dan campuran keduanya $60,5 \%$. Penyalahgunaan obat dengan jumlah 1 item persentasenya 15,8\%; 2 item 34,2\%; 3 item 34,2\%; 4 item 10,53\% dan 5 item 5,26\%. Status rehabilitasi pasien ketika keluar dari rumah sakit untuk new add persentasenya 5,3\%; induction 13,2\%; younger $13,2 \%$; middle $28,9 \%$; older $18,4 \%$ dan re-entry $21,1 \%$. Hasil uji statistik chi-square menunjukkan tidak ada hubungan antara status pengobatan pasien terhadap pendidikan terakhir $(p=$ $0,722)$, usia ketika pertama kali menyalahkan obat $(p=0,836)$ dan jumlah obat yang disalahgunakan $(p=0,713)$.
\end{abstract}

Kata kunci: Studi retrospektif, penyalahgunaan obat 


\begin{abstract}
Drug abuse in Indonesia experiences an increase every year. This study aimed to present a characteristic description of drug addiction patient, drug abuse pattern, patients' rehabilitation status when leaving the hospital, and to identify the relationship of patients' characteristic and the pattern of drug abuse toward patients' medical status when leaving the hospital. Data collecting was done through patient's medical record in the period of January 2012-December 2013. This study was a descriptive-analytic study with retrospective approach. Data analysis used Frequency and Chi-Square statistical test. The study result showed the percentages of patients with the last educational levels of Elementary School (34.2\%), Junior High School (36.8\%), Senior High School (26.3\%), and Diploma $3(2.6 \%)$. The patients who at the first time misused the drugs at the age of 11-19 years old were $50.0 \%$; at the age of 20-29 years old were $42.1 \%$; at the age of 30 39 years old were 7.9\%. The pattern of drug abuse for narcotics and addictive substances type was 26.3\%; for non narcotics and addictive substances type was $13.3 \%$; and for the mixture of both types was $60.5 \%$. Drug abuse with the number of 1 item was $15.8 \%$; 2 item was $34.2 \%$; 3 item was 34.2\%; 4 item was $10.53 \%$; and 5 item was 5.26\%. Patients' rehabilitation status when leaving the hospital for new add was 5.3\%; for induction was 13.2\%; for younger was 13.2\%; for middle was 28.9\%; for older was $18.4 \%$; and for re-entry was $21.1 \%$. Chi-Square test result showed that there was not any relationship among patients' medical status toward the last level of education $(p=0.72)$, the age of misusing the drugs for the first time $(p=0.84)$, and the number of drugs misused $(p=0.71)$.
\end{abstract}

Keywords: $\quad$ retrospective study, drug abuse

PENDAHULUAN

Drug abuse atau penyalahgunaan obat menurut World Health Organisation (WHO) adalah penggunaan obat-obatan atau zat kimia yang tidak ditujukan untuk pengobatan atau medikasi, akan tetapi obat-obatan tersebut dipergunakan untuk mendapat kenikmatan (Nawawi et al., 1996). NAPZA adalah singkatan dari narkotika, alkohol, psikotropika dan zat adiktif lainnya. NAPZA kadang kala disebut juga dengan istilah narkoba, singkatan dari narkotika dan obat berbahaya (Lisa \& Sutrisna, 2013).

Data terakhir yang didapat dari Badan Narkotika Nasional dan Pusat Penelitian Kesehatan Universitas Indonesia tahun 2014 diketahui prevalensi penyalahgunaan obat di Kalimantan Selatan pada tahun 2009 sebesar $1,59 \%$ yaitu 40.810 jiwa dan 
naik menjadi 1,93\% pada tahun 2012 sebanyak 52.472 jiwa. Sehingga dalam tiga tahun persentase penyalahgunaan obat di Kalimantan Selatan naik sebesar $0,34 \%$. Kenaikan persentase ini jika tidak segera ditanggulangi dapat menjadi ancaman bagi generasi muda.

Prevalensi jenis narkoba yang paling banyak digunakan setahun terakhir adalah ganja sebesar 4,9\%, Amphetamine-Type Stimulants (ATS) sebesar 2,3\%, sedangkan opioid, tranquilizer, halusinogen dan inhalan di bawah 1\%. Untuk obat non NAPZA yang paling banyak disalahgunakan adalah dekstrometorfan $\quad(0,7 \%) \quad(B N N$, 2014).

Penelitian ini dilakukan Rumah Sakit Jiwa Sambang Lihum yang merupakan tempat rehabilitasi untuk pasien penyalahgunaan obat di Kalimantan Selatan. Hasil studi pendahuluan yang dilakukan di Rumah Sakit Jiwa Sambang Lihum diketahui bahwa kombinasi obat dekstrometorfan dan alkohol paling banyak ditemukan pada riwayat pemakaian. Menurut Badan Pengawas Obat dan Makanan
(BPOM) tahun 2012 dekstrometorfan jika digunakan bersama dengan alkohol bisa menyebabkan kematian. Peran seorang farmasi cukup penting dalam hal ini guna mencegah dan menekan penyalahgunaan obat.

Model terapi di Rumah Sakit Jiwa Sambang Lihum menggunakan Therapeutic Community Model yang didasarkan pada terapi rehabilitasi berbasis komunitas. Diberlakukan status rehabilitasi pada setiap pasien yang menjalani rehabilitasi. Hal tersebut meliputi new add, induction, younger, middle, older, dan re-entry. Pihak rumah sakit menyarankan pasien menyelesaikan terapi sampai status rehabilitasi re-entry atau mengikuti rehabilitasi sampai selesai dengan harapan agar kemungkinan pasien untuk kembali menyalahgunakan obat-obatan (relapse) lebih kecil. Kenyataannya tidak sedikit pasien yang tidak menyelesaikan program rehabilitasi sampai tahapan tersebut.

Berdasarkan alasan ini, maka perlu dilakukan penelitian untuk memperoleh gambaran karakteristik pasien penyalahgunaan obat di Rumah Sakit Jiwa Sambang Lihum, 
pola penyalahgunaan obat-obatan, status rehabilitasi pasien ketika keluar dari rumah sakit dan hubungan antara karakteristik pasien dan pola penyalahgunaan obatobatan terhadap status pengobatan pasien ketika keluar dari rumah sakit.

\section{METODE PENELITIAN}

Penelitian ini merupakan penelitian observasional dengan pendekatan cross sectional dan pengambilan data secara retrospektif. Pengambilan data dilakukan melalui rekam medik pasien NAPZA di Rumah Sakit Jiwa Sambang Lihum pada periode Januari 2012 Desember 2013.

Kriteria inklusi yang digunakan adalah pasien NAPZA yang menjalani rawat inap di ruang Safir periode Januari 2012 - Desember 2013 dan pasien NAPZA yang pulang atas persetujuan dokter. Berdasarkan kriteria tersebut didapatkan jumlah subjek penelitian sebanyak 38 orang. Analisis data karakteristik pasien penyalahgunaan obat dan pola penyalahgunaan obat dilakukan secara statistik dan ditampilkan dalam bentuk deskriptif yaitu berupa tabel frekuensi, sedangkan data hubungan antara karakteristik pasien dan pola penyalahgunaan obat-obatan terhadap status pengobatan pasien ketika keluar dari rumah sakit dianalisis menggunakan uji chisquare.

\section{HASIL DAN PEMBAHASAN}

Rumah Sakit Jiwa Sambang Lihum menggunakan metode rehabilitasi Therapeutic Community Model sebagai metode terapi untuk pasien ketergantungan obat, pihak rumah sakit tidak memberlakukan adanya pemberian subtitusi obat pada pasien rehabilitasi terkait resiko penyalahgunaan obat subtitusi oleh tenaga kesehatan di rumah sakit.

$$
\text { Tahapan pengobatan rawat }
$$
inap pertama kali dimulai dari detoksifikasi. Sebelumnya pasien didampingi oleh keluarga akan melakukan registrasi atau pendataan pasien meliputi nama lengkap, tempat tanggal lahir, alamat, agama, pendidikan, nama orang tua, riwayat NAPZA yang pernah digunakan dan usia ketika pertama kali menggunakan NAPZA. Detoksifikasi 
dilakukan selama kurang lebih 14 hari. Selama kurun waktu tersebut dokter akan menentukan diagnosis, terkait gangguan jiwa akibat efek samping dari penggunaan narkoba. Rumah Sakit Jiwa Sambang Lihum menyebutkan pasien rehabilitasi ini sebagai pasien rehabilitasi NAPZA meskipun pada kenyataannya ada pasien yang tidak menggunakan NAPZA tetapi menggunakan obat bebas terbatas atau obat keras untuk disalahgunakan. NAPZA sendiri merupakan singkatan dari narkotika, psikotropika, alkohol dan zat adiktif lain (Suyasa \& Wijaya, 2006). Sehingga untuk obat yang bukan NAPZA tapi digunakan pasien untuk disalahgunakan pada penelitian ini peneliti golongkan sebagai golongan obat non NAPZA.

Tabel I. Distribusi Karakteristik Pasien Ketergantungan Obat di Rumah Sakit Jiwa Sambang Lihum Periode Januari 2012-Desember 2013

\begin{tabular}{|c|c|c|}
\hline Karakteristik Pasien & $\begin{array}{c}\text { Jumlah Pasien } \\
(\mathbf{N}=\mathbf{3 8})\end{array}$ & $\begin{array}{c}\text { Persentase } \\
(\%)\end{array}$ \\
\hline \multicolumn{3}{|l|}{ Tingkat Pendidikan Terakhir } \\
\hline $\mathrm{SD}$ & 13 & 34,2 \\
\hline SMP & 14 & 36,8 \\
\hline SMA & 10 & 26,3 \\
\hline D3 & 1 & 2,6 \\
\hline \multicolumn{3}{|c|}{ Usia Pertama Kali Menggunakan Obat-Obatan } \\
\hline $11-19$ & 19 & 50,0 \\
\hline $20-29$ & 16 & 42,1 \\
\hline $30-39$ & 3 & 7,9 \\
\hline \multicolumn{3}{|c|}{ Jenis Obat-Obatan yang disalahgunakan } \\
\hline NAPZA & 10 & 26,3 \\
\hline Non NAPZA & 5 & 13,3 \\
\hline Campuran Keduanya & 23 & 60,5 \\
\hline \multicolumn{3}{|c|}{$\begin{array}{l}\text { Jumlah Obat-Obatan yang Disalahgunakan } \\
\text { (item) }\end{array}$} \\
\hline 1 & 6 & 15,8 \\
\hline 2 & 13 & 34,2 \\
\hline 3 & 13 & 34,2 \\
\hline 4 & 4 & 10,5 \\
\hline 5 & 2 & 5,3 \\
\hline \multicolumn{3}{|c|}{ Status Pengobatan Pasien Ketika Keluar dari } \\
\hline New add & 2 & 5,3 \\
\hline Induction & 5 & 13,2 \\
\hline Younger & 5 & 13,2 \\
\hline Middle & 11 & 28,9 \\
\hline Older & 7 & 18,4 \\
\hline Re-entry & 8 & 21,1 \\
\hline
\end{tabular}


a. Tingkat Pendidikan Terakhir

Berdasarkan data pada tabel I tersebut dapat dilihat bahwa pasien paling banyak berpendidikan terakhir Sekolah Menengah Pertama (SMP) yaitu dengan persentase sebesar $36,8 \%$ atau sebanyak 14 orang tetapi persentase ini tidak berbeda jauh dengan persentase pasien yang berpendidikan terakhir Sekolah Dasar (SD) yaitu sebesar 34,2\% atau sebanyak 13 orang. Tetapi pada dasarnya pasien NAPZA yang menjalani rehabilitasi di Rumah sakit Jiwa Sambang Lihum memiliki tingkat pendidikan yang masih rendah sehingga hal tersebut bisa menjadi faktor penyebab pasien menyalahgunakan obat-obatan tanpa mengetahui akibat buruknya.

\section{Menurut Supriatna} pendidikan merupakan faktor internal yang mempengaruhi penggunaan NAPZA. Seseorang yang berpendidikan akan mengetahui mana yang baik dan mana yang buruk, mengetahui mana yang harus dilakukan dan mana yang tidak seharusnya dilakukan. Sehingga dengan pendidikan yang baik seseorang tidak akan terjerumus ke dalam permasalahan penyakitpenyakit masyarakat. Tokoh yang dianggap panutan seperti orang tua, sikap yang ditimbulkan dapat bertentangan dengan pengetahuan sehingga bernilai negatif (Anja et al., 2010).

b. Usia Pertama Kali Menggunakan Obat-Obatan

Distribusi usia pasien NAPZA di Rumah Sakit Jiwa Sambang Lihum dimulai dari 13 tahun sampai 35 tahun sehingga peneliti mengambil rentang usia 1119 tahun, 20-29 tahun, dan 30-39 tahun. Pasien paling banyak menggunakan obat-obatan pertama kali pada usia 11-19 tahun yaitu dengan persentase 50,0\%. Menurut survei yang dilakukan BNN (2014) terhadap 8.056.307 orang pekerja transportasi di Indonesia jika dilihat menurut kelompok usia pertama kali menggunakan obat-obatan, sebanyak $47 \%$ berada di kisaran usia $<20$ tahun dan sebanyak $48 \%$ berada pada usia 20-29 tahun.

Hasil penelitian pada tabel I menunjukkan bahwa pasien pertama kali menggunakan obat-obatan pada usia muda atau remaja. Menurut 
penelitian Sabarinah yang dikutip Kementrian Kesehatan RI (2014) para pemakai narkoba mengungkapkan bahwa rata-rata merokok di usia 14 tahun pada lakilaki dan 15 tahun pada perempuan, dilanjutkan mengonsumsi alkohol sekitar usia 15 tahun pada laki-laki dan 17 tahun pada perempuan, kemudian mengkonsumsi NAPZA rata-rata di usia 16 tahun pada lakilaki dan 17 tahun juga pada perempuan.

Usia remaja sangat rentan terhadap penyalahgunaan narkoba karena pada usia remaja tingkat emosi dan mental masih sangat labil, sehingga para remaja mudah terpengaruh ke dalam perilaku menyimpang. Remaja memiliki kecenderungan ingin tahu sehingga akan mencari informasi mengenai narkoba. Oleh karena itu, dengan mendapat informasi tersebut remaja dapat membentuk sikap dan perilaku yang menjauhi penyalahgunaan narkoba. Namun, dapat pula dengan sikap ingin mencari berbagai sumber informasi tentang narkoba, remaja akan cenderung memiliki potensi memakai narkoba misalnya dimulai dengan sekedar coba-coba (Narendra et al., 2012; Jamshid \& Mohammad, 2012). Rasa ingin tahu terhadap narkotika dan psikotropika merupakan salah satu pendorong bagi seseorang untuk melakukan perbuatan yang menyimpang termasuk keingintahuan terhadap NAPZA yang pada akhirnya dapat menimbulkan ketergantungan (Syam, 2007).

Kepribadian seseorang dipengaruhi oleh tingkat kecerdasan emosi yang dimiliki. Rilley dan Schutte dalam Handoko (2009) menyebutkan bahwa prediktor penting dalam permasalahan penyalahgunaan NAPZA adalah kecerdasan emosional yang rendah. Pada usia remaja tingkat kecerdasan masih rendah sehingga rentan melakukan penyalahgunaan NAPZA. Faktor internal yang menyebabkan usia remaja termasuk kelompok penyalahguna narkoba adalah faktor rasa ingin tahu atau coba-coba (60\%), ingin dihargai, dan depresi (20\%) serta kurangnya nilai-nilai agama (60\%). Faktor eksternal penyebab penyalahgunaan narkoba usia remaja adalah pengaruh teman 
sebaya (65\%), kurangnya perhatian orang tua (52\%), broken home (45\%), dan media massa (80\%) (Alfgeir et al., 2013).

\section{c. Jenis Obat-Obatan Yang}

Disalahgunakan

$$
\text { Jenis obat-obatan pada }
$$
penelitian ini digolongkan menjadi 3 kelompok yaitu NAPZA, non NAPZA dan campuran keduanya. Kelompok NAPZA termasuk didalamnya narkotika, psikotropika, alkohol dan zat adiktif. Kelompok non NAPZA termasuk didalamnya obat keras dan obat bebas terbatas yang disalahgunakan, dan kelompok campuran yang merupakan penggunaan bersama NAPZA dan non NAPZA. Pada tabel I memperlihatkan bahwa pasien di Rumah Sakit Jiwa Sambang Lihum paling banyak menggunakan campuran antara NAPZA dan non NAPZA yaitu dengan persentase sebesar $60,5 \%$.

\section{Jenis NAPZA yang} disalahgunakan oleh pasien adalah metamfetamin; alkohol; $3,4 \quad-$ metilen dioksi metamfetamin (MDMA); heroin; inhalan (seperti bensin dan lem); alprazolam dan ganja. Heroin dan ganja termasuk dalam narkotika golongan I berdasarkan UU No. 35 Tahun 2009. Metamfetamin, dan MDMA termasuk dalam psikotropika golongan I berdasarkan UU No. 5 Tahun 1997, sedangkan alprazolam termasuk dalam psikotropika golongan IV. Alkohol dan inhalan termasuk dalam zat adiktif (Lestari, 2013).

Kelompok obat non NAPZA yang disalahgunakan oleh pasien termasuk didalamnya adalah Dekstrometorfan, $\quad$ Mixadin $®$, Mixagrip ${ }^{\circledR}$, Carnopen $\AA$, Somadril $\AA$, Oskadon ${ }^{\circledR}$, Bodrex ${ }^{\circledR}$, dan Efedrin.

Hasil studi yang dilakukan pada rekam medik periode Januari 2012 sampai Desember 2013 memperlihatkan penyalahgunaan obat yang paling banyak yang ditemukan adalah dekstrometorfan yang dikombinasikan bersama alkohol (tabel II). Menurut survei yang dilakukan oleh BNN tahun 2014 menyatakan bahwa prevalensi jenis NAPZA yang paling banyak 
Tabel II. Distribusi Penggunaan Jenis Obat-Obatan Yang Disalahgunakan PasienKetergantungan Obat di Rumah Sakit Jiwa Sambang Lihum Periode Januari 2012-Desember 2013

\begin{tabular}{|c|c|c|}
\hline \multicolumn{2}{|c|}{ Jenis Obat-Obatan Yang Disalahgunakan } & Jumlah (orang) \\
\hline \multirow[t]{7}{*}{ NAPZA } & Metamfetamin+ alkohol & 3 \\
\hline & Metamfetamin + MDMA + alkohol & 2 \\
\hline & Heroin & 1 \\
\hline & Metamfetamin + alkohol + lem & 1 \\
\hline & Inhalan & 1 \\
\hline & MDMA + Metamfetamin & 1 \\
\hline & Metamfetamin & 1 \\
\hline \multirow{3}{*}{$\begin{array}{l}\text { Non } \\
\text { NAPZA }\end{array}$} & Dekstrometorfan & 3 \\
\hline & Mixadin $₫+$ mixagrip $\AA$ & 1 \\
\hline & Oskadon $\AA$ + efedrin + somadril $\AA$ + carnopen $\AA$ & 1 \\
\hline \multirow[t]{15}{*}{ Campuran } & Dekstrometorfan + alkohol & 7 \\
\hline & $\begin{array}{l}\text { Dekstrometorfan }+ \text { Metamfetamin }+ \text { carnopen }{ }^{\circledR}+ \\
\text { alkohol }\end{array}$ & 1 \\
\hline & Dekstrometorfan + carnopen ${ }^{\circledR}+$ alkohol & 4 \\
\hline & Dekstrometorfan + MDMA + alkohol & 1 \\
\hline & Dekstrometorfan + pil koplo + alkohol & 1 \\
\hline & Dekstrometorfan + sabu + alkohol & 1 \\
\hline & Dekstrometorfan + alkohol & 1 \\
\hline & $\begin{array}{l}\text { Alprazolam } ®+\text { MDMA + somadril } ®+\text { Metamfetamin } \\
+ \text { alkohol }\end{array}$ & 1 \\
\hline & $\begin{array}{l}\text { Dekstrometorfan + Metamfetamin + MDMA + alkohol } \\
+ \text { carnopen } \AA\end{array}$ & 1 \\
\hline & Kodein + bodrex ${ }^{\circledR}+$ alkohol & 1 \\
\hline & Dekstrometorfan + alkohol + carnopen ${ }^{\circledR}+$ lem & 1 \\
\hline & Alkohol + carnopen $\AA+$ lem & 1 \\
\hline & MDMA + Metamfetamin + alkohol + carnopen $\AA$ & 1 \\
\hline & Metamfetamin + carnopen $®+$ ganja & 1 \\
\hline & Total & 38 \\
\hline
\end{tabular}

digunakan di Indonesia setahun terakhir adalah ganja yaitu dengan persentase $4,9 \%$ sedangkan untuk obat non NAPZA seperti dekstrometorfan hanya $0,7 \%$. Hasil survei ini berbeda dengan hasil penelitian dimana penggunaan dekstrometorfan lebih banyak dibandingkan penggunaan ganja.

\section{Dekstrometorfan banyak} disalahgunakan disebabkan obat ini mudah didapat secara bebas baik di apotek maupun di warung-warung. Harga dekstrometorfan relatif murah. Selain itu, masyarakat beranggapan bahwa obat bebas itu aman sehingga penyalahgunaannya lebih aman dibandingkan dengan obat golongan narkotika atau psikotropika (BPOM, 2012).

Heroin berikatan dan mengaktivasi reseptor spesifik di 
otak yang dinamakan mu-opioid receptors (MORs) (Waldhoer, et al., 2004). Ketika MORs diaktivasi di otak, maka akan menstimulasi pelepasan neurotransmitter dopamin yang menyebabkan sensasi kesenangan. (National Institute of Drug Abuse, 2014). THC dan zat kimia cannabinoid dalam ganja mirip dengan zat kimia cannabinoid yang secara alami ada di dalam tubuh. Akibat kemiripan ini, THC bisa berikatan pada reseptor cannabinoid dan mengaktivasinya, mengacaukan banyak fungsi mental dan fisik (National Institute of Drug Abuse, 2015).

Metamfetamin dan MDMA termasuk dalam psikotropika golongan I berdasarkan UndangUndang RI Nomor 5 Tahun 1997. Penggunaan pada dosis yang berlebihan dari metamfetamin dapat menyebabkan kejang-kejang, gagal pernafasan, serangan jantung dan stroke (BNN, 2012).

MDMA menyebabkan neurotransmitter serotonin, dopamin dan norepineprin lepas dari tempat penyimpanannya menyebabkan peningkatan efek peningkatan suasana hati oleh penggunanya (National Institute of Drug Abuse, 2006).

Alprazolam termasuk dalam psikotropika golongan IV berdasarkan Undang-Undang No 5 Tahun 1997. Alprazolam menghambat re-uptake serotonin dan noradrenalin di ujung-ujung saraf otak dan dengan demikian memperpanjang waktu tersedianya neurotransmitter tersebut (Tjay \& Rahardja, 2007).

Alkohol dan inhalan termasuk dalam zat adiktif. Alkohol menekan susunan saraf pusat, jika digunakan dengan campuran dengan narkotika atau psikotropika akan memperkuat pengaruh zat tersebut di dalam tubuh (Lestari, 2013). Kematian ketika menyalahgunakan inhalan dapat terjadi akibat gangguan jantung (aritmia) atau akibat tertekannya pernapasan (pengap) karena penyaluran oksigen ke peredaran darah dihambat akibat sel paru-paru tertutup oleh uap pelarut (Tjay \& Rahardja, 2003).

Mixadin $® \quad$ mengandung dekstrometorfan $\mathrm{HBr}$ yang dapat 
mengakibatkan efek halusinogen (BPOM, 2012). Selain itu obat ini juga mengandung efedrin yang merupakan prekursor berdasarkan Undang-Undang No 35 Tahun 2009. Penyalahgunaan efedrin dalam waktu lama dapat menyebabkan timbulnya gejala skizoprenia paranoid (Depkes RI, 2007).

\section{Fenilpropanolamin}

(norefedrin) yang terkandung dalam Mixagrip ${ }^{\circledR}$ juga termasuk dalam golongan prekursor berdasarkan Undang-Undang No 35 Tahun 2009. Hasil penelitian menunjukkan adanya hubungan antara fenilpropanolamin dan stroke, maka pada dalam bulan April 2001 peredaran produk-produk (khususnya obat flu) yang mengandung bahan aktif ini di atas $15 \mathrm{mg}$ per takaran telah ditarik dari peredaran (Tjay \& Rahardja, 2007)

\section{Oskadon ${ }^{\circledR} \quad$ dan $\quad$ Bodrex ${ }^{\circledR}$} merupakan obat yang digunakan untuk menghilangkan nyeri (ISFI, 2010). Kedua obat ini mengandung kafein yang biasanya digunakan sebagai zat penyegar, menghilangkan rasa letih, lapar dan mengantuk, juga meningkatkan konsentrasi dan kewaspadaan (Sasangka, 2003).
Carnopen ${ }^{\circledR}$ dan Somadril ${ }^{\circledR}$ mengandung karisoprodol (ISFI, 2010). Berdasarkan penelitian Reeves \& Parker (2003) menyatakan bahwa ada gejala putus obat setelah mengonsumsi karisoprodol dan karisoprodol merupakan obat yang berpotensi untuk disalahgunakan.

d. Jumlah Obat Yang

Disalahgunakan

Jumlah obat yang disalahgunakan oleh pasien Rumah Sakit Jiwa Sambang Lihum bervariasi dari 1 sampai 5 item. Berdasarkan tabel I diketahui pasien lebih banyak menggunakan obatobatan dengan jumlah 2-3 item yaitu dengan persentase sebesar $34,2 \%$.

Secara klinis ketergantungan obat-obatan memberikan gambaran yang berbeda-beda dan tergantung banyak faktor seperti jumlah dan jenis obat yang dikonsumsi, kondisi umum dan psikiatri, konteks sosial dan lingkungan pengguna (Depkes RI, 2002). Ragam masalah yang ditimbulkan tergantung pada jenis atau gabungan narkotika yang digunakan, lama dan cara pemakaian, status gizi, status kesehatan fisik, 
serta mental dari pengguna $(\mathrm{BNN}$,

2012). Selain itu menurut Kepmenkes RI (2010) efek obatobatan terhadap pengguna dipengaruhi oleh banyak faktor, salah satunya adalah obat-obatan lain yang digunakan bersamaan. Karena itu peneliti merasa perlu mengetahui kombinasi jumlah obat-obatan yang disalahgunakan oleh pasien.

\section{e. Status Pengobatan Pasien Ketika Keluar dari Rumah Sakit}

Berdasarkan tabel I diketahui status pengobatan pasien ketika keluar dari rumah sakit paling banyak adalah status pengobatan middle dengan persentase $28,95 \%$. Hasil tersebut memperlihatkan bahwa tingkat kesadaran pasien untuk berobat sudah cukup tinggi dengan sedikitnya pasien yang keluar pada status pengobatan new add.

Menurut Ariskasuci (2008) seorang mantan pecandu yang kembali ke lingkungan keluarga, lingkungan tempat tinggal, dan lingkungan kerja mengalami reaksi dan hambatan dalam berinteraksi yang berasal dari stigma negatif yang ada dalam masyarakat yang dapat memperbesar kemungkinan terjadinya relapse atau kembali menggunakan obat-obatan. Diharapkan dengan mengikuti program sampai selesai kemungkinan pasien untuk relapse lebih rendah, dikarenakan pada status pengobatan re-entry inilah pasien dipersiapkan sebelum dikembalikan ke masyarakat.

f. Hubungan Tingkat Pendidikan Terakhir Pasien Terhadap Status Pengobatan Pasien Ketika Keluar dari Rumah Sakit

Data karakteristik pasien pada tabel I memperlihatkan bahwa pasien yang menyelesaikan program rehabilitasi sampai status pengobatan re-entry $21,0 \%$ atau hanya sebanyak 8 orang dari jumlah 38 pasien. Status pengobatan ini menduduki urutan kedua setelah middle sebagai status pengobatan pasien ketika keluar dari rumah sakit. Berdasarkan hasil tersebut peneliti ingin mengetahui faktor-faktor apa saja yang mungkin dapat mempengaruhi kepatuhan pasien mengikuti program rehabilitasi sampai selesai pada pasien ketergantungan obat di Rumah Sakit Jiwa Sambang Lihum. 


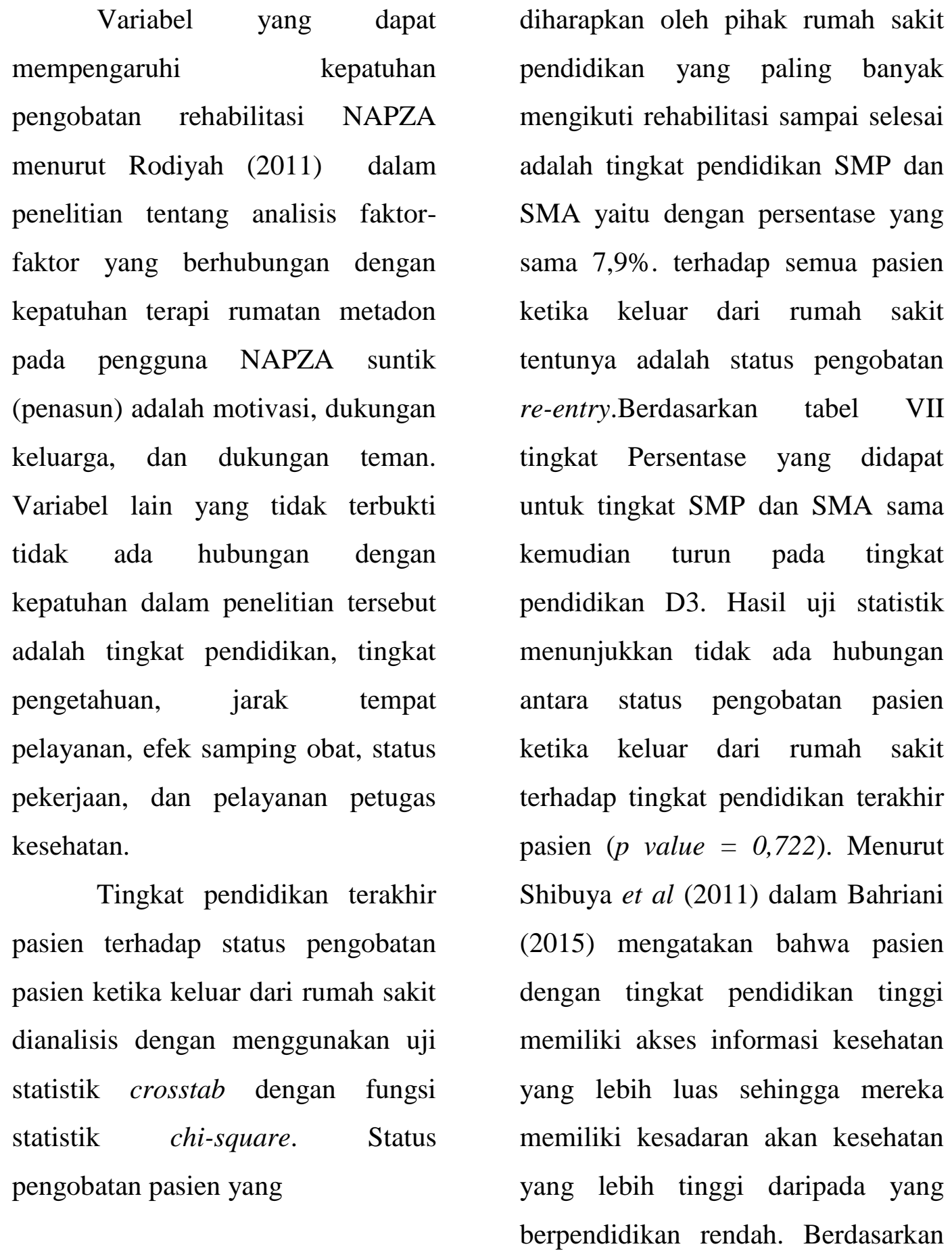


Tabel IV. Hubungan Tingkat Pendidikan Terakhir Pasien Terhadap Status Pengobatan Pasien Ketika Keluar dari Rumah Sakit

\begin{tabular}{|c|c|c|c|c|c|c|c|c|c|}
\hline \multirow{3}{*}{$\begin{array}{c}\text { Status pasien } \\
\text { ketika keluar } \\
\text { dari rumah } \\
\text { sakit }\end{array}$} & \multicolumn{8}{|c|}{ Tingkat Pendidikan Terakhir Pasien } & \multirow{3}{*}{$\begin{array}{c}\mathbf{P} \\
\text { value }\end{array}$} \\
\hline & \multicolumn{2}{|c|}{ SD } & \multicolumn{2}{|c|}{ SMP } & \multicolumn{2}{|c|}{ SMA } & \multicolumn{2}{|c|}{ D3 } & \\
\hline & $\mathrm{f}$ & $\%$ & $\mathrm{f}$ & $\%$ & $\mathrm{f}$ & $\%$ & $\mathrm{f}$ & $\%$ & \\
\hline New add & 1 & 2,6 & 1 & 2,6 & 0 & 0,0 & 0 & 0,0 & \\
\hline Induction & 2 & 5,3 & 3 & 7,9 & 0 & 0,0 & 0 & 0,0 & \\
\hline Younger & 1 & 2,6 & 2 & 5,3 & 1 & 2,6 & 1 & 2,6 & \\
\hline Middle & 4 & 10,5 & 3 & 7,9 & 4 & 10,5 & 0 & 0,0 & 0,722 \\
\hline Older & 3 & 7,9 & 2 & 5,3 & 2 & 5,3 & 0 & 0,0 & \\
\hline Re-entry & 2 & 5,3 & 3 & 7,9 & 3 & 7,9 & 0 & 0,0 & \\
\hline Total & 13 & 34,2 & 14 & 36,8 & 10 & 26,3 & 1 & 2,6 & \\
\hline
\end{tabular}

teori ini diharapkan pasien dengan tingkat pendidikan tinggi mengikuti rehabilitasi sampai selesai dikarenakan akses informasi kesehatan yang dimilikinya lebih luas sehingga kesadaran akan kesehatannya juga lebih tinggi.

g. Hubungan Usia Pemakaian ObatObatan Pertama Kali Terhadap Status Pengobatan Pasien Ketika Keluar dari Rumah Sakit

Usia merupakan salah satu faktor yang mempengaruhi kepatuhan secara umum (Brunner \& Suddarth, 2002). Perbandingan antara usia pemakaian obatan-obatan pertama kali terhadap status pengobatan pasien dimaksudkan untuk mengetahui pasien yang terpapar dengan penyalahgunaan obat-obatan sejak usia muda mengikuti program rehabilitasi sampai selesai atau tidak. Pasien dengan riwayat pemakaian obatobatan sejak usia muda akan cenderung lebih sulit terlepas dari pengaruh penggunaan obat-obatan kembali.

Berdasarkan tabel I dapat dilihat bahwa pasien yang menggunakan obat-obatan pertama kali pada rentang usia 20-29 tahun adalah pasien yang paling banyak mengikuti rehabilitasi sampai selesai atau sampai pada status pengobatan re-entry. Hasil uji statistik menggunakan uji chi-square menunjukkan tidak ada hubungan antara usia pemakaian obat-obatan pertama kali terhadap status pengobatan pasien ( $p$ value $=0,836)$. 
Tabel V. Hubungan Usia Pemakaian Obat-Obatan Pertama Kali Terhadap Status Pengobatan Pasien Ketika Keluar dari Rumah Sakit

\begin{tabular}{|c|c|c|c|c|c|c|c|}
\hline \multirow{3}{*}{$\begin{array}{c}\text { Status pasien } \\
\text { ketika keluar } \\
\text { dari rumah sakit }\end{array}$} & \multicolumn{6}{|c|}{ Usia pemakaian obat-obatan pertama kali } & \multirow{3}{*}{$\begin{array}{c}\mathbf{P} \\
\text { value }\end{array}$} \\
\hline & \multicolumn{2}{|c|}{ 11-19 tahun } & \multicolumn{2}{|c|}{ 20-29 tahun } & \multicolumn{2}{|c|}{ 30-39 tahun } & \\
\hline & $\mathrm{f}$ & $\%$ & $\mathrm{f}$ & $\%$ & $\mathrm{f}$ & $\%$ & \\
\hline New add & 1 & 2,6 & 1 & 2,6 & 0 & 0,0 & \\
\hline Induction & 2 & 5,3 & 3 & 7,9 & 0 & 0,0 & \\
\hline Younger & 4 & 10,5 & 1 & 2,6 & 0 & 0,0 & \\
\hline Middle & 5 & 13,2 & 4 & 10,5 & 2 & 5,3 & 0,836 \\
\hline Older & 4 & 10,5 & 3 & 7,9 & 0 & 0,0 & \\
\hline Re-entry & 3 & 7,9 & 4 & 10,5 & 1 & 2,6 & \\
\hline Total & 19 & 50,0 & 16 & 42,1 & 3 & 7,9 & \\
\hline
\end{tabular}

h. Hubungan Jumlah Obat-Obatan Yang Disalahgunakan Terhadap Status Pengobatan Pasien Ketika Keluar dari Rumah Sakit Efek NAPZA terhadap pengguna dipengaruhi oleh banyak faktor, salah satunya adalah NAPZA lain yang digunakan bersamaan (Kepmenkes RI, 2010). Berdasarkan tabel I dapat dilihat bahwa pasien yang menggunakan obat-obatan 3 item paling banyak menyelesaikan rehabilitasi sampai status pengobatan re-entry yaitu dengan jumlah 4 orang atau sebesar $10,5 \%$. Hasil uji statistik pada tabel IV menunjukkan tidak ada hubungan antara jumlah obat-obatan yang disalahgunakan terhadap status pengobatan pasien $(p$ value $=0,713)$.

Pada penelitian ini terdapat beberapa keterbatasan dalam melihat hubungan antara karakteristik pasien dan pola penyalahgunaan obat terhadap status pengobatan pasien ketika keluar dari rumah sakit. Terdapat faktor lain yang tidak dapat dilihat hubungannya terhadap status pengobatan pasien yaitu keadaan ekonomi pasien. Hal ini dikarenakan keterbatasan data rekam medik yang tidak menyajikan tingkat penghasilan atau pekerjaan pasien. Padahal variabel ini juga merupakan faktor penyebab pasien tidak mengikuti program rehabilitasi sampai selesai. Oleh karena itu, untuk penelitian selanjutnya diharapkan peneliti dapat mengatasi keterbatasan tersebut dengan mengetahui tingkat penghasilan atau pekerjaan pasien. Selain itu, juga dapat dilihat variabel lain yang mungkin dapat mempengaruhi kepatuhan pasien mengikuti program rehabilitasi sampai selesai seperti status perkawinan dan dukungan keluarga. 
Tabel IV. Hubungan Jumlah Obat-Obatan Yang Disalahgunakan Terhadap Status Pengobatan Pasien Ketika Keluar dari Rumah Sakit.

\begin{tabular}{|c|c|c|c|c|c|c|c|c|c|c|c|}
\hline \multirow{3}{*}{$\begin{array}{c}\text { Status pasien } \\
\text { ketika keluar } \\
\text { dari rumah } \\
\text { sakit }\end{array}$} & \multicolumn{10}{|c|}{ Jumlah Obat yang Disalahgunakan } & \multirow{3}{*}{$\begin{array}{c}\mathrm{P} \\
\text { value }\end{array}$} \\
\hline & \multicolumn{2}{|c|}{1 item } & \multicolumn{2}{|c|}{2 item } & \multicolumn{2}{|c|}{3 item } & \multicolumn{2}{|c|}{4 item } & \multicolumn{2}{|c|}{5 item } & \\
\hline & $\mathrm{f}$ & $\%$ & $\mathrm{f}$ & $\%$ & $\mathrm{f}$ & $\%$ & $\mathrm{f}$ & $\%$ & $\mathrm{f}$ & $\%$ & \\
\hline New add & 1 & 2,6 & 0 & 0,0 & 0 & 0,0 & 1 & 2,6 & 0 & 0,0 & \\
\hline Induction & 0 & 0,0 & 2 & 5,3 & 2 & 5,3 & 1 & 2,6 & 0 & 0,0 & \\
\hline Younger & 2 & 5,3 & 1 & 2,6 & 1 & 2,6 & 1 & 2,6 & 0 & 0,0 & 0,535 \\
\hline Middle & 1 & 2,6 & 3 & 7,9 & 4 & 10,5 & 1 & 2,6 & 2 & 5,3 & \\
\hline Older & 1 & 2,6 & 4 & 10,5 & 2 & 5,3 & 0 & 0,0 & 0 & 0,0 & \\
\hline Re-entry & 1 & 2,6 & 3 & 7,9 & 4 & 10,5 & 0 & 0,0 & 0 & 0,0 & \\
\hline Total & 6 & 15,8 & 13 & 34,2 & 13 & 34,2 & 4 & 10,5 & 2 & 5,3 & \\
\hline
\end{tabular}

\section{KESIMPULAN}

Kesimpulan dari penelitian ini adalah sebagai berikut:

1. Karakteristik pasien ketergantungan obat di Rumah Sakit Jiwa Sambang Lihum dengan tingkat pendidikan terakhir SD, SMP, SMA dan D3 persentasenya berturut-turut sebesar $34,2 \%, 36,8 \%, 26,3 \%$ dan 2,6\%. Pasien menyalahgunakan obat-obatan pertama kali pada rentang usia 11-19, 20-29, 30-39 tahun persentasenya berturut-turut sebesar $50,0 \%, 42,1 \%$ dan $7,9 \%$.

2. Pola penyalahgunaan obat-obatan di Rumah Sakit Jiwa Sambang Lihum untuk penyalahgunaan NAPZA, non NAPZA, dan campuran keduanya persentasenya berturut-turut sebesar 26,3\%, 13,3\% dan 60,5\%. Penyalahgunaan obat dengan jumlah penyalahgunaan $1,2,3,4$, 5 item persentasenya berturutturut sebesar 15,8\%, 34,2\%, $34,2 \%, 10,53 \%$ dan $5,26 \%$.

3. Status rehabilitasi pasien ketika keluar dari Rumah Sakit Jiwa
Sambang Lihum pada status pengobatan new add, induction, younger, middle, older dan reentry persentasenya berturut-turut sebesar $5,3 \%, 13,2 \%, 13,2 \%$, $28,9 \%, 18,4 \%$ dan $21,1 \%$.

4. Tidak ada hubungan antara status pengobatan pasien terhadap pendidikan terakhir pasien $(p=$ $0,722)$, usia ketika pertama kali menyalahkan obat-obatan ( $p=$ 0,836), dan jumlah obat-obatan yang disalahgunakan $(p=0,713)$.

\section{UCAPAN TERIMA KASIH}

Penulis mengucapkan terima kasih kepada:

(1) Direktur Rumah Sakit Jiwa Sambang Lihum Provinsi Kalimantan Selatan

(2) Ketua Komite Etik Fakultas Kedokteran Universitas Lambung Mangkurat 


\section{DAFTAR PUSTAKA}

BNN, 2012, Buku Pedoman Penggolongan Narkotika Berdasarkan Undang-Undang Nomor 35 Tahun 2009 Tentang Narkotika, Badan Narkotika Nasional Republik Indonesia. Jakarta: 4.

BNN, 2014, Jurnal Data Pencegahan dan Pemberantasan Penyalahgunaan dan Peredaran Gelap Narkoba (P4GN) Tahun 2013 Edisi Tahun 2014, Badan Narkotika Nasional, Jakarta:121.

Brunner \& Suddarth, 2002, Buku Ajar Keperawatan Medikal Bedah, Edisi 8, Penerbit EGC, Jakarta:

BPOM RI, 2012, Mengenal Penyalahgunaan dekstrometorfan, Info POM,. 13(6) : 4. ISSN 18299334.

Depkes RI, 2007, Pharmaceutical Care Untuk Penyakit Asma, Direktorat Bina Farmasi Komunitas dan Klinik Ditjen Bina Kefarmasian dan Alat Kesehatan, Jakarta: 31 .

Kepmenkes RI, 2010, Pedoman Layanan Terapi dan Rehabilitasi Komprehensif pada Gangguan Penggunaan NAPZA Berbasis Rumah Sakit, Keputusan Menteri Kesehatan Republik Indonesia Nomor 420/menkes/sk/iii/2010, Jakarta: 23.

Lestari, S. I., 2013, Strategi Badan Narkotika Nasional Kota Samarinda Dalam Menanggulangi Penggunaan Narkoba Di Kelurahan Sungai Pinang Dalam Kota Samarinda, Journal Ilmu Pemerintahan.1(2) : 10. ISSN 2338-3651.
Lisa, F.R.J \& N.W. Sutrisna., 2013, Narkoba, Psikotropika, dan Gangguan Jiwa, Tinjauan Kesehatan Hukum, Nuha Medika, Yogyakarta: 1.

Nawawi, A.R., J. Marsamun, Y., Burhan, H., Dasuki., Dekky., 1996, Selamatkan Generasi Muda Bangsa dari Bahaya Penyalahgunaan Narkotika. BP. Dharma Bakti. Jakarta.

NIDA., 2006, Research Report Series: MDMA (Ecstasy) Abuse. US Department of Health and Human Services, National Institute of on Drug Abuse, USA: 5.

NIDA, 2015, Research Report Series: Marijuana, US Department of Health and Human Services, National Institute of on Drug Abuse, USA: 5.

Reeves, R.R. \& J.D. Parker., 2003, Somatic Dysfunction During Carisoprodol Cessation: Evidence For A Carisoprodol Withdrawal Syndrome, JAOA Original Contribution.,103(2) : 75.

Sasangka, H., 2003, Narkotika dan Psikotropika dalam Hukum Pidana. Mandar Maju. Bandung.

Supriatna, A., 2012, Upaya Pencegahan dan Penyembuhan Patologi Sosial Penyalahgunaan Narkotika Berbasis Keagamaan. Tesis (tidak diterbitkan). Universitas Pendidikan Indonesia.

Suyasa, P.T.Y.S \& F Wijaya., 2010, Resiliensi dan Sikap Terhadap Penyalahgunaan Zat (Studi Pada Remaja). Jurnal Psikologi. 4(2) : 106. 
Tjay, T.H. \& K. Rahardja., 2003, Obat-Obat Penting, Khasiat, Penggunaan, dan Efek-Efek Sampingnya, Edisi ke-6, PT Elex Media Komputindo, Jakarta: 344, 437,459 .

Waldhoer, M., S.E. Bartlett, J.L.

Whistler., 2004, Opioid

Receptors. Annu Rev Biochem 73: 953. 